\title{
Action Research on Application of Cooperative Learning in Business English-Viewing, Listening \& Speaking*
}

\author{
XIANG Chun-yan \\ Binzhou University, Binzhou, China
}

\begin{abstract}
Business English-Viewing, Listening \& Speaking is a practical course for business English majors. Cooperative learning is the teaching mode mainly based on the group work. The author applied the cooperative learning in the teaching for 10 weeks. The action research attempts to investigate the feasibility and effectiveness of cooperative learning through teaching practice, questionnaire, interview, and classroom observation. The results show that cooperative learning can improve the learning behavior, and facilitate the students' communicating skills.
\end{abstract}

Keywords: Business English, cooperative learning, action research

\section{Introduction}

The latest College English Curriculum Requirements published by China's Ministry of Education in 2007, is an important document for the current college English teaching in China. It raises new requests for both college students and college English teachers. Teachers need to help students develop their ability to use English in all aspects especially in listening and speaking, and finally communicate fluently in their future effectively, and at the same time enhance their ability to study independently and improve their general cultural awareness so as to meet the needs of China's social development and international exchanges. However, many Chinese students are still the passive acceptors rather than active participants in class activities. And also nowadays, with the increasing enrollment of college students and the enlargement of the English class, how to teach a bigger class is also a question for teachers. So all the above have posted great challeges for college English teachers. They should make changes in their roles, their teaching beliefs, and teaching approaches, and it is urgent that they should figure out how to foster active classroom interaction between teachers and students, thus providing students with an environment where they are able to participate in class activities actively. The current study aims to investigate the feasibility and effectiveness of cooperative learning in college English teaching, listening, and speaking.

\section{Theory Overview and Background}

Action research, a teaching theory and research method for the exploration and practice in education, serves

\footnotetext{
* Acknowledgements: This research is supported by 山东省高校人文社科研究项目 (Research Project of Humanity and Social Science in Colleges and Universities of Shandong Province J15WD26); 滨州学院教学研究项目 (Teaching Research Project of Binzhou University BYJYZD201305, BYJYWZ201337).

XIANG Chun-yan, lecturer, M.A., Foreign Language Department, Binzhou University.
} 
for the improvement of teaching methods and teaching results through teachers' reflection in teaching. Teachers, namely researchers, research into the projects identified based on problems exposed in class and resort to reflection for the improvement of teaching. The action research usually involves several parts as follows: finding problems and putting forward research projects, laying out plans and taking steps, analyzing and evaluating the results. New problems may be exposed after the implementation of the process. So the steps above will be continued.

Cooperative learning is a learning method based on group motivation theory, cognitive theory, and social constructivism. It contains the mutual aid learning groups that stem with internal cooperation and external competition where obligations are clear and definite to each student.

Modern education focuses on the personal development of students and attempts to cultivate students' capability of independent learning which has collected the public concern. Researchers are putting their eyes to the cooperative learning. Cooperative learning serves indispensably for the development of cooperative and competitive awareness. Meanwhile, its application should coincide with specific situation in teaching practice, considering special requirements of various subjects, individual and other factors.

Business English-Viewing, Listening \& Speaking, a curriculum designed for the improvement of the comprehensive language skills of business English majors, aims to enhance students' capability of comprehension and expression. Through the integration of viewing, listening, and speaking, students can get progress in listening and speaking under the training of spoken English with intuitionistic scenes and plots; besides, they can enrich knowledge related to business and foreign trade from instruction by teachers. In respect of the training of listening, students are supposed to receive a system of strict training in business activities. Nevertheless, time limited, seldom can students have opportunities to practice spoken English in class. In the teaching program of professional English enacted by the Ministry of Education, it is pointed out that the three aspects, namely, teaching imparting, capability training, and diathesis lift should be balanced well; it is explicitly required that students should have the competence to communicate and cooperate, to put forward personal proposals, and to join in discussion, as well as communicating competence, collaborative skills, organizing skills, and other skills. Nonetheless, in teaching practice, the author found that the majority of students lacking in initiative and enthusiasm for learning, instead, they are awaiting for the teacher's mechanical questions. In the mode of cooperative learning, students are supposed to fulfill the personal task on the basis of positive interaction and complete the common task by cooperation. As long as the appropriate measures to be taken, cooperative learning could be effectively applied to the teaching of Business English-Viewing, Listening \& Speaking, to change the students' learning attitude and learning behavior.

\section{Research Design}

Two intact classes were selected from the second-year students majoring in business English at Binzhou University. Those overall 76 students (class A 37 and class B 39), 14 boys and 62 girls, were taken as the research subjects. The study applied questionnaire, interview, and class observation. On the basis of relevant references and combined with teaching practice, the author conducted questionnaires and interviews throughout the experiment, conducted the classroom observation as well. The research was divided into three phases. First is the pre-experimental phase. Every targeted student got the questionnaire and was included in interviews. Through the collation and analysis of the aforementioned work results, combined with classroom observation, the author 
investigated students' cooperative awareness. Second is the application phase of cooperative learning. In conformity with the teaching program, meanwhile, considering the characteristics of business English and the subject, the author applied cooperative learning in the teaching for 10 weeks to test the feasibility of its application into Business English-Viewing, Listening \& Speaking and explore practical strategies. Third is the post-experimental phase. At the end of one-semester of cooperative learning, the author collected information on the feedback of cooperative learning through second-round questionnaires and interviews, and put it in compare with the pre-experimental situation to find whether there are any changes on students' learning attitude, learning behaviors, and cooperative awareness.

\section{Research Process and Results Analysis}

\section{Pre-experimental Results and Analysis}

In the pre-experimental phase, 76 questionnaires were sent out to research subjects and were all taken back, with a valid response rate of $100 \%$. The questionnaire involves 12 questions of two aspects: questions 1 to 8 are about the learning attitude and behavior, and 9 to 12, the cooperative awareness. For each question, there are three options available numbered A, B, and C, which respectively mean "consent", "uncertainty", and "dissent", and there are no standard answers. For the pre-experimental findings, see Table 1 as follows.

Table 1

Pre-experimental Questionnaires (\%)

\begin{tabular}{lllllllllllll}
\hline \multicolumn{2}{l}{ Learning attitude } & behavior and cooperative awareness \\
\hline Sort & 1 & 2 & 3 & 4 & 5 & 6 & 7 & 8 & 9 & 10 & 11 & 12 \\
\hline A & 61 & 83 & 86 & 70 & 29 & 61 & 65 & 87 & 35 & 88 & 75 & 73 \\
B & 20 & 10 & 10 & 16 & 40 & 21 & 23 & 10 & 50 & 8 & 16 & 20 \\
C & 19 & 7 & 4 & 14 & 31 & 18 & 12 & 3 & 15 & 4 & 9 & 7 \\
\hline
\end{tabular}

According to Table 1, the majority of students enjoyed the course; $86 \%$ of students were able to actively participate in the listening and speaking training while 39\% were not satisfied with their oral English skills; there were students who cared for communicating in English, but only accounted for a small proportion of the total, whereas $71 \%$ embraced passive or negative attitudes to cooperative learning; most students were fond of this curriculum, and $88 \%$ believed it could contribute to the communicating skill. The table also reflected students' poor cooperative awareness, for $35 \%$ liked cooperating with partners while $50 \%$ held that whether it contributed to their study progress was uncertain.

According to the results above, the author took interviews with students and conducted classroom observation. The findings are as follows: Most students rendered it important to practice oral English for the sake of the improvement of communicating skills, but only a fraction would like to perform. Some thought that expressing themselves in oral English, distinct from previous reading and writing training, made them uneasy. Some defined them as spoken inferiority and were unconfident in speaking English for fear of being laughed at. Besides, there were much doubt of the teaching mode based on the teacher's interpretation and combined with direct questions or personal reports because only a few who usually performed positively intended to answer questions whereas most students lacked opportunities to speak out as class time is limited. Some considered cooperative learning as a matter of squandering on sitting around. And for those with weak elementary 
knowledge, they deemed it little effective to improve themselves. There were a large number of students confused about how to conduct effective exchanges and collaboration with others.

Through the pre-experiment, the author had a general knowledge of relevant situations. The results showed that the traditional teaching mode cannot effectively contribute to students' communicating skills.

\section{The Experimental Process}

The author applied the cooperative learning in the teaching for 10 weeks, and the textbook adopted was New Horizon Business English-Viewing, Listening \& Speaking published by Foreign Language Teaching and Research Press.

At the beginning of the semester, on the principle of heterogeneousness inside groups and homogeneousness among groups, students were divided into several groups. Class A was divided into seven subgroups, with each group made up of five students on average but two groups consisting of six students; Class B eight subgroups with five students on average but one group four students. The academic achievements, personalities, and learning styles varied from person to person for the sake of inter-group structural consistency. In the training prior to the experiment, the author explained to students the connotation and function of cooperative learning and how to learn cooperatively.

The author employed two types of activities including group investigation and role plays which were conducted as per the research results as well as characteristics of the curriculum and by means of the cases enclosed in the textbook.

Much information and material like company profile and product introduction are compiled in the New Horizon Business English-Viewing, Listening \& Speaking. Considering the fact that students were passive listeners under the traditional teaching mode of "teaching and listening", the author guided the students to study in collaboration to improve their ability of listening and speaking. The students were free to select the company and products they would like to make a presentation of and then referred to relevant information in line with their division of responsibilities. The results for the final report presented by the group in class were originated from group discussion and accepted evaluation. Marks and comments were given by other groups in conformity of the criterion the teacher laid down. For the final mark, the teacher contributed to $60 \%$ and the peer assessment was responsible for the rest $40 \%$.

After interviews, problems were exposed as follows: Some students distracted from others' reports; students with weak spoken English dared not give reports publicly and feared of being a drag on the whole group; in some groups, common discussion was limited especially in the case that some students just recited the speech draft prepared by able students. The author carried out some solutions to these problems. First, the teacher's questioning was involved. Questions related to the report of one group raised by the teacher awaited answers from other groups. The students would be graded on daily performance. Second, the teacher demonstrated the participation, learning attitude, and learning progress. Third, the students were required to submit audiotapes or videotapes about their discussions.

In group role playing, every group was required to role-play the videos about business cases after their adaptation and innovation. Through the experiment and interviews, the author found that the students recited their parts respectively rather than rehearsed together, besides, they gave a rather wooden performance, merely reciting facts that they have learned by rote. Resolutions are as follows. First, videotapes of the whole rehearse 
were required. Second, students were required to blend into the virtual business situation instead of cramming sentence patterns. Particularly, eye contact and tone mattered a great deal. The author showed students how to perform theatrically by means of tone of voice and movement.

\section{Post-experimental Results and Analysis}

Through nine-week experiment, the author sent out 76 questionnaires and 76 were taken back, effective and valid. Two questions are added: question No. 13 entitled "I enjoy the cooperative learning" and No. 14 entitled "The cooperative learning improved my learning ability". The results were as concluded in Table 2.

Table 2

Pre-experimental Questionnaires (\%)

\begin{tabular}{lllllllllllllll}
\hline \multicolumn{2}{l}{ Learning attitude \& behavior and cooperative awareness } \\
\hline Sort & 1 & 2 & 3 & 4 & 5 & 6 & 7 & 8 & 9 & 10 & 11 & 12 & 13 & 14 \\
\hline A & 70 & 91 & 88 & 80 & 73 & 71 & 83 & 89 & 79 & 88 & 70 & 74 & 88 & 82 \\
B & 11 & 3 & 6 & 11 & 11 & 11 & 10 & 8 & 11 & 8 & 23 & 7 & 9 & 10 \\
C & 19 & 2 & 6 & 9 & 16 & 18 & 7 & 3 & 10 & 4 & 7 & 11 & 3 & 8 \\
\hline
\end{tabular}

According to Table 2, the majority of students held positive to improve their English and were willing to communicate with others. $91 \%$ of the students took to the curriculum, $80 \%$ were able to answer questions in English, and 83\% would like to join in discussion and analysis. Most students believed that the curriculum would benefit them in interaction. $88 \%$ were fond of the cooperative learning and $82 \%$ rendered that it facilitated self-learning ability.

According to the interview, a number of students expressed their enthusiasm of cooperative learning and group activities in Business English-Viewing, Listening \& Speaking. They admitted that they had experienced skills lift in communication and collaboration through role plays with both their spoken English and confidence lifted. The cooperative learning helped them to communicate more naturally and smoothly, and provided them with chances to learn from others in that there were more interactions among group members. The teacher-student interaction and that of student-student made the class vivid and students enthusiastic to communicate in English, by this way learning efficiency and confidence were improved. Although a fraction of students deemed that they were still stressed for their spoken inferiority, the author noticed that those who used to keep silent in class were more confident to express themselves in English after the experiment.

Furthermore, the author compared the results of pre-experiment and post-experiment to find whether there were distinct changes in students' learning attitude and behavior and their cooperative awareness. The results are as follows in Table 3:

Table 3

Contrasts Between Pre-experiment and Pot-experiment (\%)

\begin{tabular}{llllllllllllll}
\hline \multicolumn{2}{l}{ Learning attitude \& behavior and cooperative awareness } \\
\hline Sort & 1 & 2 & 3 & 4 & 5 & 6 & 7 & 8 & 9 & 10 & 11 & 12 \\
\hline A Pre & 61 & 83 & 86 & 70 & 29 & 61 & 65 & 87 & 35 & 88 & 75 & 73 \\
Post & 70 & 91 & 88 & 80 & 73 & 71 & 83 & 89 & 79 & 88 & 70 & 74 & 16 \\
B Pre & 20 & 10 & 10 & 16 & 40 & 21 & 23 & 10 & 50 & 8 & 16 & 20 & 7 \\
Post & 11 & 3 & 6 & 11 & 11 & 11 & 10 & 8 & 11 & 8 & 23 & 7 \\
C Pre & 19 & 7 & 4 & 14 & 31 & 18 & 12 & 3 & 15 & 4 & 9 & 7 \\
Post & 19 & 2 & 6 & 9 & 16 & 18 & 7 & 3 & 10 & 4 & 7 & 11 \\
\hline
\end{tabular}


Table 3 showed the large increase in students' interests of learning English. The proportion of students fond of the curriculum increased from $50 \%$ to $91 \%$, the proportion in favor of the curriculum's benefit to communicative ability increased from $36 \%$ to $90 \%$, and the proportion that enjoyed the cooperative learning increased from $31 \%$ to $86 \%$. In respect of the confidence and cooperative skills, increases were limited. In general, the cooperative learning improved the learning behavior, and facilitated the students' communicating skills.

\section{Conclusion}

Business English-Viewing, Listening \& Speaking, a practical course for business English majors, aims to enhance students' competence to take professional knowledge into practice. It has been experimented that cooperative learning, the teaching mode mainly based on the group work, facilitates both teaching and learning. Through cooperative learning, students are more confident and interested in spoken English now. The teacher-student interaction and that of student-student creates a harmonious classroom atmosphere, and after class, students can learn initiatively and cooperatively. The results show that cooperative learning develops the cooperative awareness, and facilitates the students' communicating skills and skills of using English.

Besides, as to those students with weak elementary knowledge and learning motivation as well as high level of anxiety, their learning behavior has not been significantly improved. The countermeasures hereto in cooperative teaching deserve further investigations. To better apply the cooperative learning in the teaching for the sake of the improvement of the teaching quality, the scope as well as deadline of research could be extended and individual cases should be focused on in future studies.

\section{References}

Johnson, D., \& Johnson, R. (1995). Learning together and alone: Cooperative competitive and individualistic learning. New Jersey: Prentice Hall.

Kessler, C. (1992). Cooperative language learning: A teacher resource book. NJ: Prentice Hall.

Nunan, D. (1993). Action research in language education. Oxford: Heinemann.

Nunan, D., \& Bailey, K. M. (2009). Exploring second language classroom research: A comprehensive guide. Beijing: Foreign Language Teaching and Research Press.

Van Lier, L. (1999). The classroom and the language learner. Singapore: Longman Singapore Publishers. 
Appendix

Questionnaire of English Learning Attitude and Behavior and Cooperative Awareness.

Question 1: I like the course of Viewing, Listening \& Speaking.
A. Consent
B. Uncertainty
C. Dissent

Question 2: I am intersted in English.
A. Consent
B. Uncertainty
C. Dissent

Question 3: I am willing to communicate wiht others in English learning.
A. Consent
B. Uncertainty
C. Dissent

Question 4: I think participating positively in class is very important for improving English communicationg skills.
A. Consent
B. Uncertainty
C. Dissent

Question 5: I can express myself in English in class.
A. Consent
B. Uncertainty
C. Dissent

Question 6: I can take part in class activies actively.
A. Consent
B. Uncertainty
C. Dissent

Question 7: I can improve my speaking through this course.
A. Consent
B. Uncertainty
C. Dissent

Question 8: I can improve my speaking through this course.
A. Consent
B. Uncertainty
C. Dissent

Question 9: I can express my ideas in cooperative activities.
A. Consent
B. Uncertainty
C. Dissent

Question 10: I can take part in cooperatvie activities in English learning.
A. Consent
B. Uncertainty
C. Dissent

Question 11: I can learn from others in cooperatvie activities in English learning.
A. Consent
B. Uncertainty
C. Dissent

Question 12: I am satisfied with my performance in cooperatvie activities in English learning.
A. Consent
B. Uncertainty
C. Dissent

Question 13: I enjoy the cooperative learning.
A. Consent
B. Uncertainty
C. Dissent

Question 14: The cooperative learning can improve my learning ability.
A. Consent
B. Uncertainty
C. Dissent 